\title{
Flags of Convenience and Global Capitalism
}

By

\section{Anthony van Fossen}

\section{Anthony van Fossen}

Email: a.vanfossen@griffith.edu.au

Affiliation: School of Humanities, Languages and Social Science, Griffith University, Brisbane, Australia

Mailing Address:

School of Humanities, Languages, and Social Science

Macrossan Building

Griffith University

Nathan, Queensland 4111

Australia 


\title{
Flags of Convenience and Global Capitalism ${ }^{* 1}$
}

\author{
Anthony van Fossen
}

School of Humanities, Languages and Social Science, Griffith University, Brisbane, Australia

\begin{abstract}
The flags of convenience (FOC) shipping system promotes laissez-faire global capitalist development and has become dominant in providing the legal framework for ocean commerce in recent decades, as it has largely replaced the national flag shipping system. FOCs reduce the powers of nation-states in taxing, owning, and regulating property; controlling competition; setting wage rates and working conditions; and providing environmental protection. The growing use of FOCs arises from shipowners' world-wide shopping for laws that they are willing to pay for- to ensure the strongest private property rights and neoliberal capitalist conceptions of efficiency. FOC are offered to foreigners by tax havens or offshore financial centres in small states such as Panama, Liberia, and the Marshall Islands. Flags from these open registers have a crucial role in drastically reducing transportation costs, vastly increasing the scale of maritime trade, and providing viability to globally integrated systems of production, distribution and consumption, as well as shifting power away from traditional centres of influence. FOCs push for a low tax, low wage, libertarian system of global capitalism, yet they unintentionally contribute to chronic instability_-bubbles, overcapacity, and severe downturns in shipping and the wider global political economy.
\end{abstract}

KEYWORDS

Flag of convenience; global capitalism; transnational capitalist class; libertarianism, tax haven

Capitalism reached a crisis in the late 1960s, for which globalization was the answer. But the national flag shipping system of that time was far too expensive and restrictive to allow a global capitalism to emerge. A novel libertarian ${ }^{2}$ transoceanic system developed to solve these crucial problems. This global transportation system is based on flags of convenience (FOCs), the maritime component of offshore tax havens.

Shipping is central to the global economy, but it receives virtually no attention in standard texts ${ }^{3}$ of economics (Frank and Bernanke 2013; Krugman, Wells and Graddy. 2008, Samuelson and Nordhaus 2010), international political economy (Pettman 2012), or globalization studies (Michie 2011; Ritzer 2012). The same neglect is shown toward transportation in general. ${ }^{4}$ Flags of convenience are very rarely, if ever, mentioned in these conventional accounts, despite their crucial role in bringing down the costs of global transportation. This article extends critical globalization studies, which have begun to explore the importance of shipping in creating the contemporary world (Bonacich and Wilson 2008; Dicken 2015). ${ }^{5}$

In the last fifty years, since 1965, transoceanic maritime trade has grown at more than twice the general world economic growth rate (Dicken 2015; Stopford 2009). During these five decades flag of convenience shipping has increasingly dominated global trade, growing at more than ten times the general world economic growth rate. ${ }^{6}$ FOCs are crucial to the trade networks that have created global capitalism, but their importance is very rarely recognised in the existing literature.

Flags of convenience are offered by tax havens (van Fossen 2012b; 2016) — overwhelmingly to foreigners. An offshore financial centre (OFC) is a tax haven jurisdiction which attracts the business of foreigners by

- $\quad$ creating legal entities and structures (e.g., ship, oil rig, or airplane registrations; companies; trusts; partnerships; banks; insurance companies; leasing arrangements)

- $\quad$ accepting deposits and investment funds

\footnotetext{
* CONTACT: Anthony van Fossen

Email: a.vanfossen@griffith.edu.au

${ }^{1}$ An earlier version of this paper was presented at the Conference of the Network for the Critical Study of Global Capitalism, Charles University of Prague, on September 26-27, 2015.

${ }^{2}$ Libertarianism is laissez-faire liberalism which limits proper governmental activity to (at most) police protection, national defence, and the enforcement of contracts.

${ }^{3}$ Standard textbooks, handbooks and encyclopedias accurately reflect widely accepted views in an area of research and study.

${ }^{4}$ Academic attention to tariff reduction is disproportionately great in comparison.

${ }^{5}$ Dicken $(2015,86-7)$ only briefly considers container shipping, but he suggests that it is greatly underrated and it is one of the most important businesses of the last three decades.

${ }^{6}$ Since 1965, transoceanic maritime trade has grown at more than twice the general world economic growth rate (Dicken 2015, Stopford 2009) and the percentage of world tonnage flying FOCs has grown by a factor of more than five (see table 4).
} 
- facilitating immigration, naturalization, residence, or the acquisition of passports

to allow foreigners to minimise taxes, regulation, loss of assets, unwanted financial disclosure and forced disposition of property. OFCs have become very important, but little recognised, players in the global economy since 1973-little recognised partly because they are all in small states, mostly in very small microstates. This paper concentrates on a specific tax haven business - the maritime flag of convenience (see table 1 ).

Table 1. Major flags of convenience.

Table - 1

Major Flags of Convenience*

\begin{tabular}{|l|l|}
\hline \multicolumn{1}{|c|}{ Country } & Region \\
\hline Antigua and Barbuda & Caribbean \\
\hline Bahamas & Caribbean \\
\hline Bermuda & Caribbean \\
\hline Cayman Islands & Caribbean \\
\hline Cyprus & Europe \\
\hline Gibraltar & Europe \\
\hline Hong Kong & Asia \\
\hline Isle of Man & Europe \\
\hline Liberia & Africa \\
\hline Malta & Europe \\
\hline Marshall Islands & Pacific \\
\hline Panama & Central America \\
\hline Singapore & Asia \\
\hline St. Vincent \& the Grenadines & Caribbean \\
\hline Vanuatu & Pacific \\
\hline
\end{tabular}

*Major Flags of Convenience are defined as those that registered vessels of more than 2,000,000 gross tons in 2010 . Source: Lloyd's Register of Shipping, World Fleet Statistics, 2011.

Source: Lloyd's Register of Shipping, World Fleet Statistics, 2011

A flag of convenience is a legal identity for a ship, offshore oil platform, offshore maritime space launching pad, or other offshore ocean object registered easily for a fee in a jurisdiction where it is not ultimately owned, for the purpose of commercial or tax advantages. The flag of a ship is important because it determines most of the applicable laws governing taxation, labour practices, safety, licensing, inspection and management, although there may be conflicts with the laws of port states, which sometimes have precedence. ${ }^{7}$ This relationship is represented by maritime flags—vessels flying the merchant ensign of the port state together with their own when in a foreign port.

FOCs are part of what Harris (2005, 2013, 2014), Robinson (2004, 2014) and Robinson and Harris (2000) have analysed as Global Capitalism. Since the late 1960s and early 1970s, there has been profound qualitative change in the capitalist mode of production-creating a new structure of global capitalism dominated by the transnational capitalist class and an emerging transnational state.

This paper interprets this transition in terms of the simultaneous movement from a national flag industrial cargo shipping system to a flag of convenience global cargo shipping system. For convenience in the remainder of this paper, these shall be referred to as the national flag system and the flag of convenience system, respectively.

\section{National flag industrial cargo shipping system}

The national flag industrial cargo shipping system developed as economies became internationalised. There were drastic reductions in shipping costs after oceangoing steamships arrived in the 1840s. The

\footnotetext{
${ }^{7}$ Although these laws have general application, there are conflicts between laws and even internal contradictions within them. In addition, powerful economic, political and social forces benefit from or are disadvantaged by laws and influence how they are interpreted and (not) applied. The result of this situation is that, whatever general applicability the laws may have, the actual outcome of the application of these laws in any particular legal case may be indeterminate, contradictory and somewhat incoherent (Kennedy 1997).
} 
national flag system was powered by steam (and then diesel) steel ships with iron hulls and screw propellers. In the national flag system there was widespread dissemination of current price and shipping information by telegraph and newspaper and (eventually) radio and long distance telephone. This was made possible by the deep sea cable - which allowed shipping to be planned far better than before. There was general transportation by national flag crews on national flag vessels. These were owned by nationalistic owners, especially from large and dominant countries (such as the United Kingdom, the United States, Germany, France, and the USSR). Institutions in these same national states financed, regulated, taxed and subsidised their own national fleets. This national flag system was still dominant in the mid-1960s, with Liberia the only major FOC, notably providing flags for most globalised form of capitalism at that time- the oil industry and its tankers (see table 2).

Table 2. Top ten maritime flags as a percentage of gross tons of registered vessels, December 31, 1965.

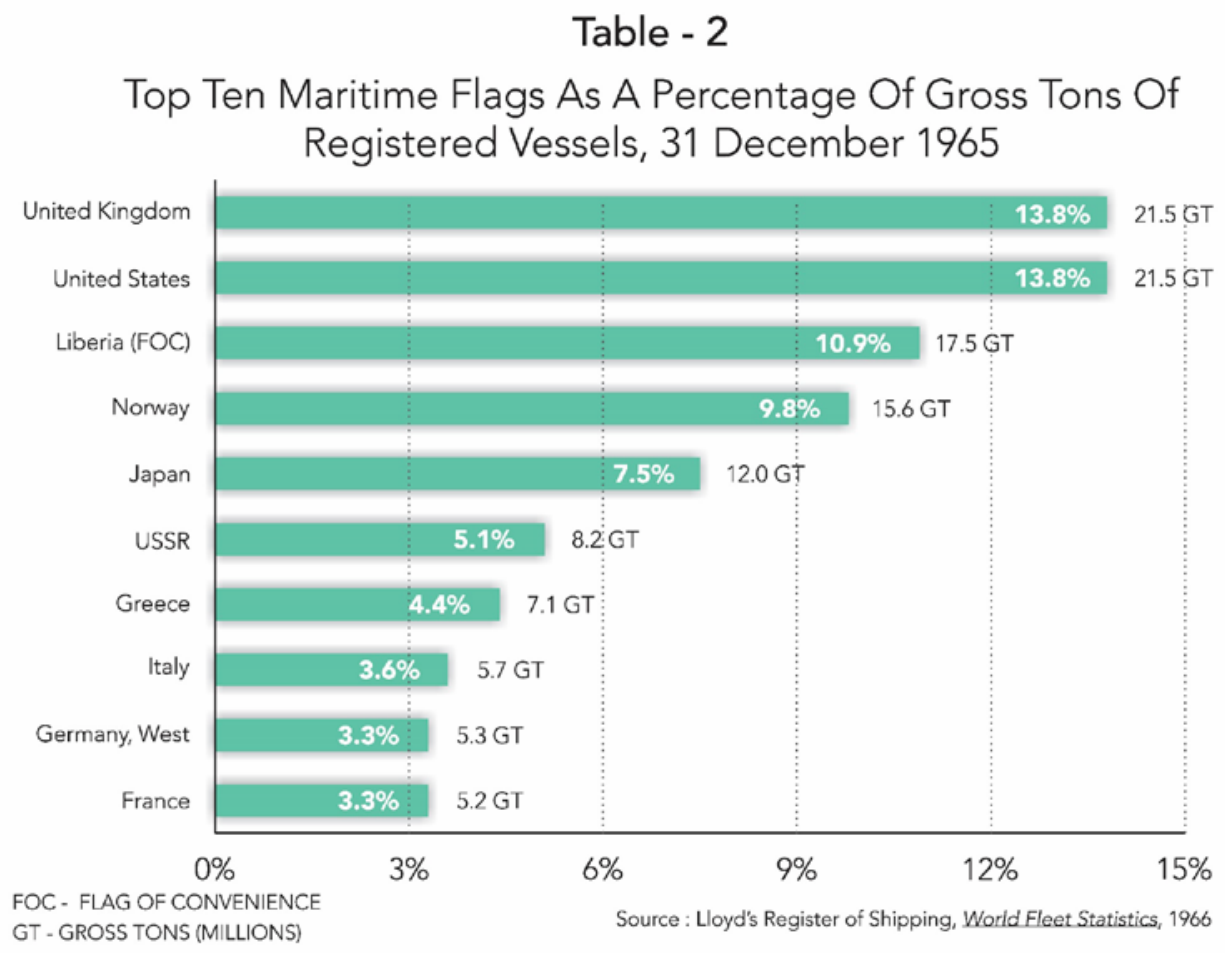

Shipping was inextricably tied to nationalism, nation-building and projecting national interests into the international arena. Nationalism was especially strong in the liner sector-where large companies (each strongly linked to a national flag) owned large, regularly scheduled ocean liners carrying general cargo in accord with published rates. In the tramp sector, small companies owned less sophisticated ships flying national flags (often of less powerful countries, such as Norway and Greece). They carried bulk and residual general freight at rates negotiated for each trip. National flag shipping's growth generally was dependent on a favourable balance of international power to provide peace.

National flag shipping was highly visible in the ports of the central business districts of citieswith ships' national flags being immediately recognisable and highly meaningful. The system was based on transporting nationally defined raw materials and finished goods, largely centred on the imperial/colonial system of European states or national spheres of influence (Harlaftis 1996; Heidbrink 2011; Miller 2012; Stopford 2009).

The only significant institutional change in the national flag system from 1890 to the 1960s was organised labour's emergence and its integration into the power structures of the shipping industry. By the mid-1960s workers were increasingly protected by national unions and national welfare states. They shipped goods of growing nationally-based industries, with rising wages and increasing taxes on capital in a Fordist-Keynesian system. Levels of international trade in the early 1960s were no higher than they had been in the 1920s. ${ }^{8}$

\footnotetext{
${ }^{8}$ In the US, for example, international trade made up a smaller proportion of the national economy in 1960 than it did in 1930. In 1961 ocean freight expenses constituted $10 \%$ and $12 \%$ of the value of American imports and
} 
Within a decade, by the mid-1970s, economic crises reduced world trade and freight rates fellwith fewer cargoes and severe overcapacity. Shipowners found that their largest operational costsfrom national labour, taxes and regulations_could be sharply reduced by abandoning national flags and adopting a rising number of flags of convenience. Vessels flying FOCs were increasingly financed through offshore tax haven arrangements, drawing on capital from around the world and further reducing costs and national constraints (for example, by permitting the owner to build the vessel at the cheapest shipyards around the world, rather than in the national flag state). This new, inexpensive flag of convenience shipping system allows a qualitative transformation toward globalization-the increasing functional integration of economic activities across vastly extensive geographical scales, where trade growth shifted to Asian economies (Lane 2007; Stopford 2009).

Global capitalism and FOCs have increasingly structured the world since the late 1960s and early 1970s. They are part of the same historical wave, expedited by the (i) crumbling of national capitalism, (ii) evaporation of European empires, (iii) decline of US hegemony, (iv) disintegration of Keynesian/Bretton Woods system, (v) massive growth of financialisation with floating exchange rates, (vi) rise of neo-Fordism, post-Fordism and neo-liberalism, (vii) weakening of social democracy and (viii) virtual collapse of Leninism (Robinson 2014).

The flag of convenience is identified with global capitalism, minimising real loyalty to any specific country and reassigning property claims and income away from their sources. Flags of convenience are postmodern deconstructions of the national flag system. FOCs maintain the forms of nationhood (flags and the laws of the flag nation-state), but empty the flags of most of their substance and the genuine links between flags, nation-states, owners and crews. Flags of convenience are simulacra or distorted copies of national flags.

Global capitalism and FOCs have developed since the late 1960s and early 1970s-alongside enormous growth of the transnational corporation (TNC), global trade, foreign direct investment and mergers and acquisitions; these have transformed production. Production has gone from being nationbased (where a complete good or service is produced in one country and traded at arm's length) to being fragmented, dispersed and decentralised around the world.

Today at least one-third of global merchandise trade occurs within TNCs (Dicken 2015, 20). FOC vessels carry most of this. FOCs play a crucial and growing role in creating the global networks that empower transnational corporations to shift production, distribution and consumption to where profits can be maximized.

The flag of convenience global cargo shipping system

Flags of convenience have increasingly replaced national flags and have become dominant as the legal and regulatory basis of the shipping system (tables $3,4,5$ ).

exports, respectively. Costs were so high in some ports as to make almost all forms of international trade virtually impossible (Levinson 2006, 8-10). 
Table - 3

Top Ten Maritime Flags As A Percentage Of Gross Tons Of Registered Vessels, 31 December 2014

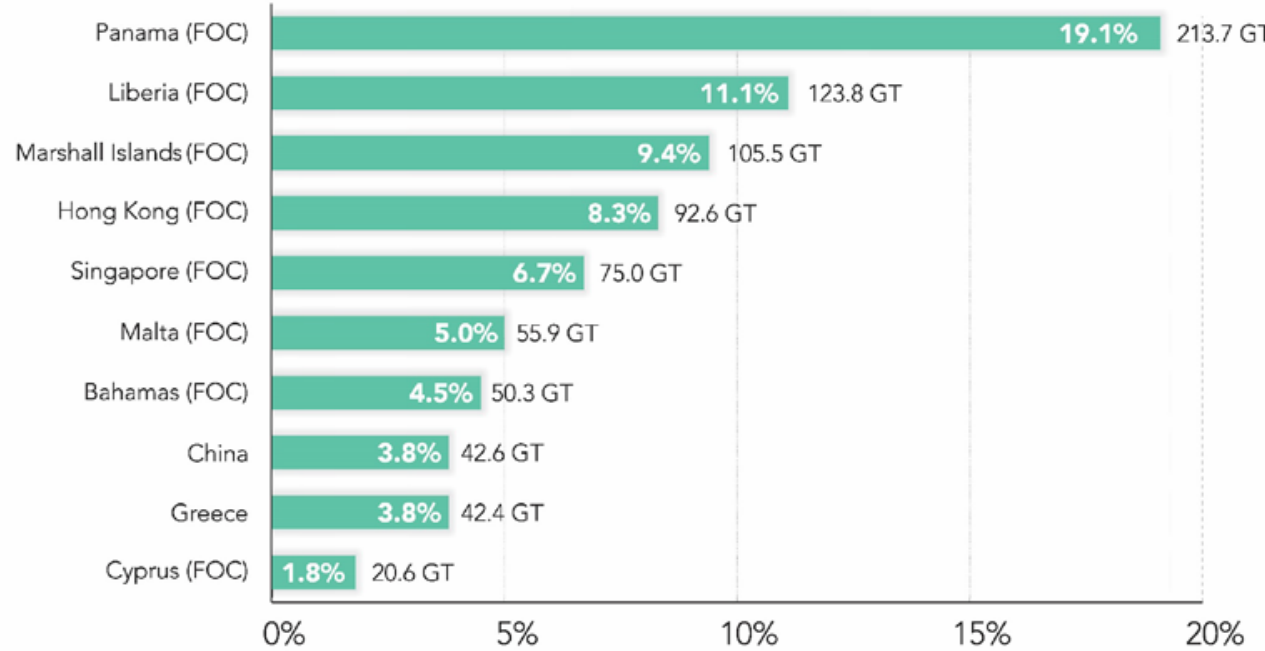

FOC - FLAG OF CONVENIENCE GT - GROSS TONS (MILLIONS)

Source : UK Department of Transport, World Fleet Statistics, 2015

Table - 4

Percentage Of World's Fleet Under Flags Of Convenience, By Gross Tons | 1955 - 2014

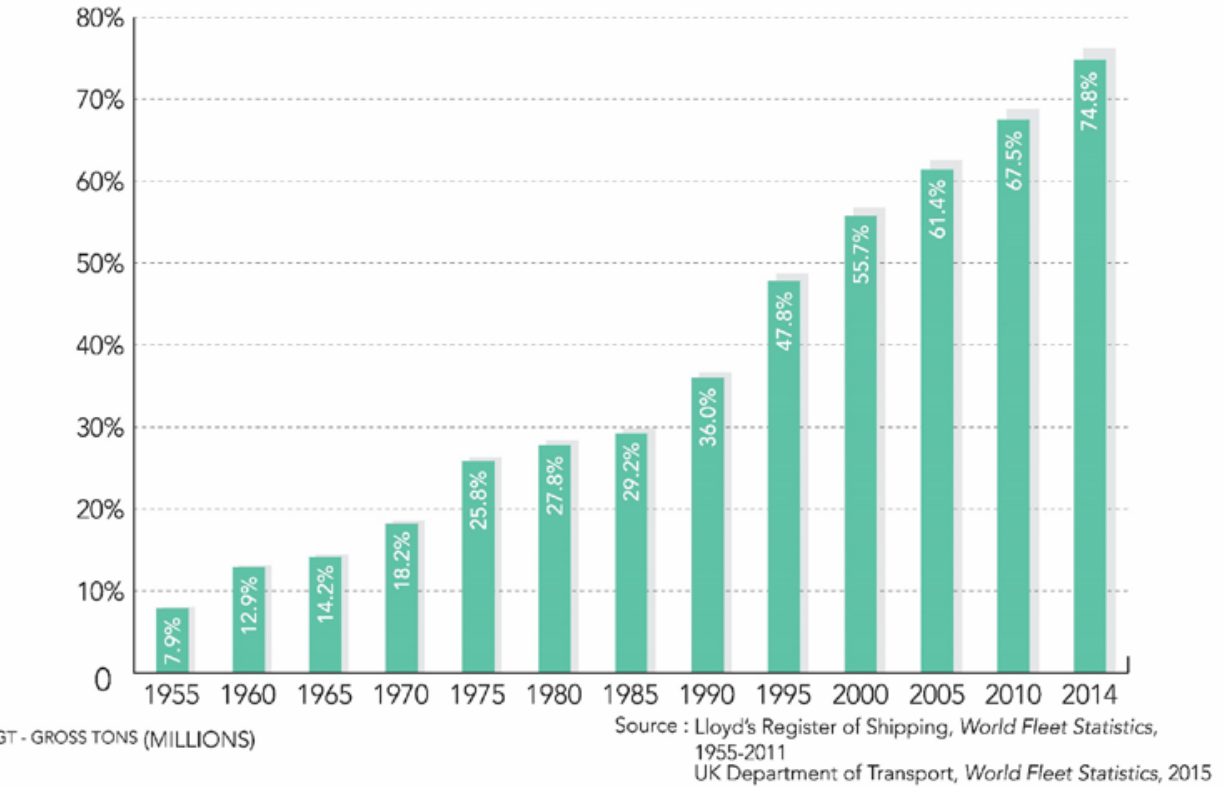




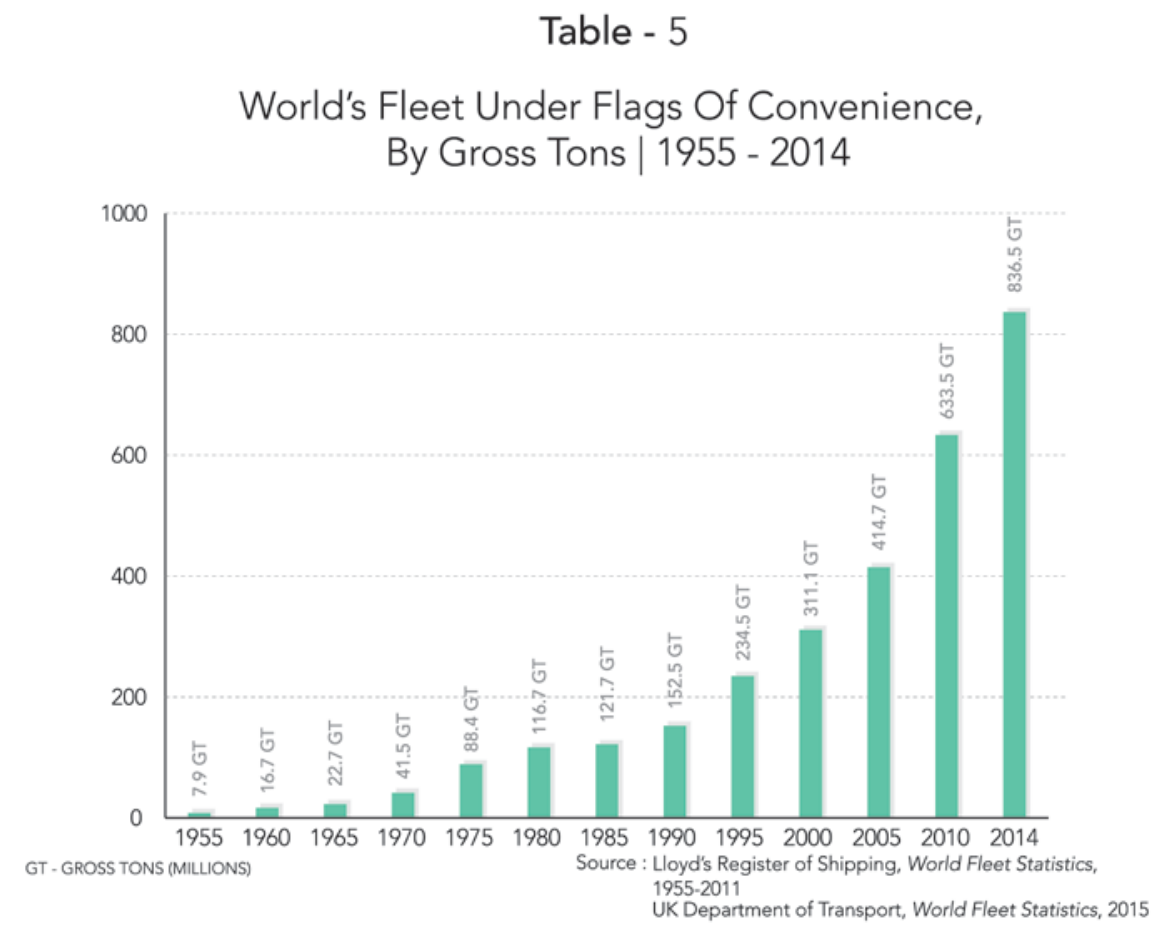

The flag of convenience global cargo system crystallized in the late twentieth century. It represents a response to crises of low profitability through flagging and domiciling vessels in tax havens-laissez-faire jurisdictions with low or no taxes and regulation, but providing access to globally-sourced, tax advantaged financing. By drastically reducing the costs of transporting goods over long distances, the FOC system allows transnational corporations to pursue globally integrated strategies that exploit variations in labour costs and tax rates across the globe. The flag of convenience system erodes home field advantages-local loyalties, national protectionism, and (for high-cost producers) the usefulness of physical proximity to customers-pressuring companies to become global to succeed.

FOC laws allow inexpensive crews to be drawn from a global labour pool. Average annual labour costs aboard German container ships, for example, were reduced by over $74 \%$ by flagging out to FOCs in 1997 (Morris and Kilkauer 2001,188). In the deregulated FOC labour system, the total number of seafarers around the world has fallen as ships have been allowed to become much larger. There has also been a radical change in the ethnic composition of ocean labour, as crew members have been increasingly drawn from countries with relatively low wages and living conditions-leading to massive unemployment among unionized, high wage seafarers from traditional maritime nations (Broeze 2002). Reduced labour costs are the chief reason for using FOCs. The cost-cutting, insecurity, low wages and poor working conditions associated with the rise of FOCs have contributed to the sharp deterioration in the attractiveness of careers and a shortage of qualified labour of between 16,000 and 65,000 officers and as many as 650,000 ratings (Lloyd's Ship Manager March 2006). "Jail with a salary" has become a common figure of speech for work at sea in the FOC system (New York Times, July 19, 2015).

As the FOC institution spread through oil tankers, dry bulk vessels, specialized ships, and container ships, it promoted deregulation of all forms of transportation (water, road, rail, and air ${ }^{9}$ ) in an increasingly intermodal global system. The new flag of convenience ships, faster and vastly larger than the national flag vessels that they replaced, reconfigure space-time because they cheaply transport immense volumes of oil, coal, mineral ores, grain, sugar, intermediate factory inputs, and consumer products all over the globe-and link seamlessly to other modes of transport.

FOC shipping companies demand new, enlarged and far more technologically sophisticated ports, with fast and automated cargo-handling. Ports, especially new ports, are increasingly commercialized, corporatized and privatized. Ports are intensifying their competition to attract business and to

\footnotetext{
${ }^{9}$ The flag of convenience institution has even had a significant impact of outer space, notably Tonga's flag of convenience for satellites (van Fossen 1999). Offshore tax havens, but not yet FOCs per se, are becoming increasingly important in aviation. 3,500 airplanes or 50\% of the global fleet of leased aircraft, are managed in the OFC of Ireland, with the OFCs of Malta, Singapore and the Cayman Islands rising as challengers (Keaveny and Murray 2013)
} 
annihilate, weaken or inhibit port unionism. Established ports in the national flag era were generally highly unionized and congested urban docklands, but these declined and in many cases even became derelict, as the new ports for FOC vessels are most likely to be created in exurban, less developed locations well served by highways and trains (and not far from airports), and where, most significantly, port worker solidarity and wage demands are relatively weak. Singapore (with its extensive offshore activities, including its large offshore financial centre and prominent flag of convenience) has been especially successful in seizing the new opportunities for port development. It is not alone-as the most developed ports today are seldom the established ports of the national flag era. New ports (with the lowest costs) have developed and become most prominent in the contemporary FOC period. Whereas in the national flag era the state concentrated on building its territorial unity through spending on bounded and cohesive national infrastructures such as railroads and highways, the flag of convenience era concentrates much more on ports and other global infrastructure connecting the nation-state to the world, rather than unifying the domestic territory (Hein 2015).

FOC seaborne operators support deregulation of land and air transportation in their drive toward unprecedented large scale integration with inland transport. The goal of FOC ship owners has increasingly become a laissez-faire global logistics system that can quickly and reliably deliver the cheapest standardized raw materials and industrial products around the world. FOC oil, bulk, and container vessels weaken the nation-state as they are all based on massive shipments of standard global units passing smoothly at top speed across national borders. ${ }^{10}$ The contents (often from all over the world) are hidden and rarely inspected, properly taxed, regulated, or even accurately recorded by national authorities. This is often seen as the epitome of global free market efficiency.

The low-cost, deregulated FOC system creates an ideal environment for the development of Export Processing Zones (EPZs), industrial tax havens. Like new ports, EPZs are usually removed in special zones shielded from traditional urban and industrial centres and the general population. They are enclaves offering investors an export-oriented infrastructure with low or no taxes, freedom from duties, exemption from a substantial number of national laws and regulations, and opportunities for repressive labour control.

The combination of FOC shipping, EPZs and the development of oil, bulk and container ports in low-wage countries leads to a reorientation of the world's manufacturing to such port-based zones. Nowhere is this more true than in China. There, since 1979, substantial areas of the country's coastline have been developed as port-based EPZs, known there as "Special Economic Zones.” This is part of a global (rather than the traditional local) orientation to development strategy. It places transnational corporations in a powerful position to influence industrial, tax and labour policies. The number of EPZs around the world has increased dramatically in recent years, especially after 2008, when they already employed about 68,000,000 people. Policy-makers see EPZs as a way to stimulate economies dragged down by sluggish domestic demand and the after-effects of the Global Financial Crisis. While there was only one EPZ in 1959, this grew to more than 4,000 EPZs in 2015 (Dicken 2015; Economist, April 4, 2015).

Global transportation links are increasingly central to comparative advantage. By driving down transportation costs, ${ }^{11}$ the FOC system assists the spatio-temporal reorganisation of capitalism by greatly reducing the insulation of national political-economic systems. It enables the systems of outsourcing, subcontracting, partnerships, and alliances that are central to the strategies of successful TNCs. FOC vessels deliver components, half-finished goods and final products in expanding global supply chains that are coordinated and tracked by new telecommunications and information technologies. The low-cost FOC system is central to a process whereby the high price inflation of the 1970s was overcome by cheap imports from far away. This system displaces domestic products from the shelves of shops in North America, Europe, Japan, and Australasia, where purchases are eased by the availability high levels of consumer credit and debt.

This globally seamless FOC shipping system is a dream for global capitalists and a nightmare for national security and customs officials and public interest groups, since it is so opaque. Ships spend very little time in port and load and unload with extraordinary speed and minimal disclosure. Ports

\footnotetext{
${ }^{10}$ Authors such as Levinson (2006) and Cudahy (2006) emphasise the extraordinary impact of container shipping on the world economy. While this is true, they do not consider that container shipping copied many of the techniques of de-unionisation, intermodalism, unitization, and fast loading/unloading of massive cargoes in new specialized, mechanised ports. Containerisation merely took up these processes from the long-distance oil and dry bulk shipping sectors. Oil and dry bulk shipping were at the vanguard and base of the remarkable growth of flag of convenience shipping and neo-liberal globalization that containerisation later built upon (Broeze 2002, 9-11).

11 The FOC system has been steadily reducing ocean shipping costs. They accounted for only $3.6 \%$ of the value of the world's imports in 2004, despite the substantial increase over the previous three decades in the distance that goods travel by sea (Stopford 2009, 89).
} 
have moved out of people's sight (and are inaccessible to the public behind fences, walls, and gates). Shipping has become almost invisible in the mass media. People seldom travel by sea these days (except on short leisure cruises), and show no real awareness that ocean transportation has greatly increased in volume and has become ever more crucial to their daily lives since the 1960s. Shipowners are notoriously secretive and seafarers are increasingly mobile, interchangeable and anonymous. The flags on their ships bear no relationship to their nationalities, where they or their cargoes are from or where they are going (except, ironically, to the extent that FOC vessels are usually prohibited from operating in the territorial waters of the jurisdiction that flagged them). Table 6 illustrates the lack of loyalty to the national flag of shipowners in the top ten ship owning nations.

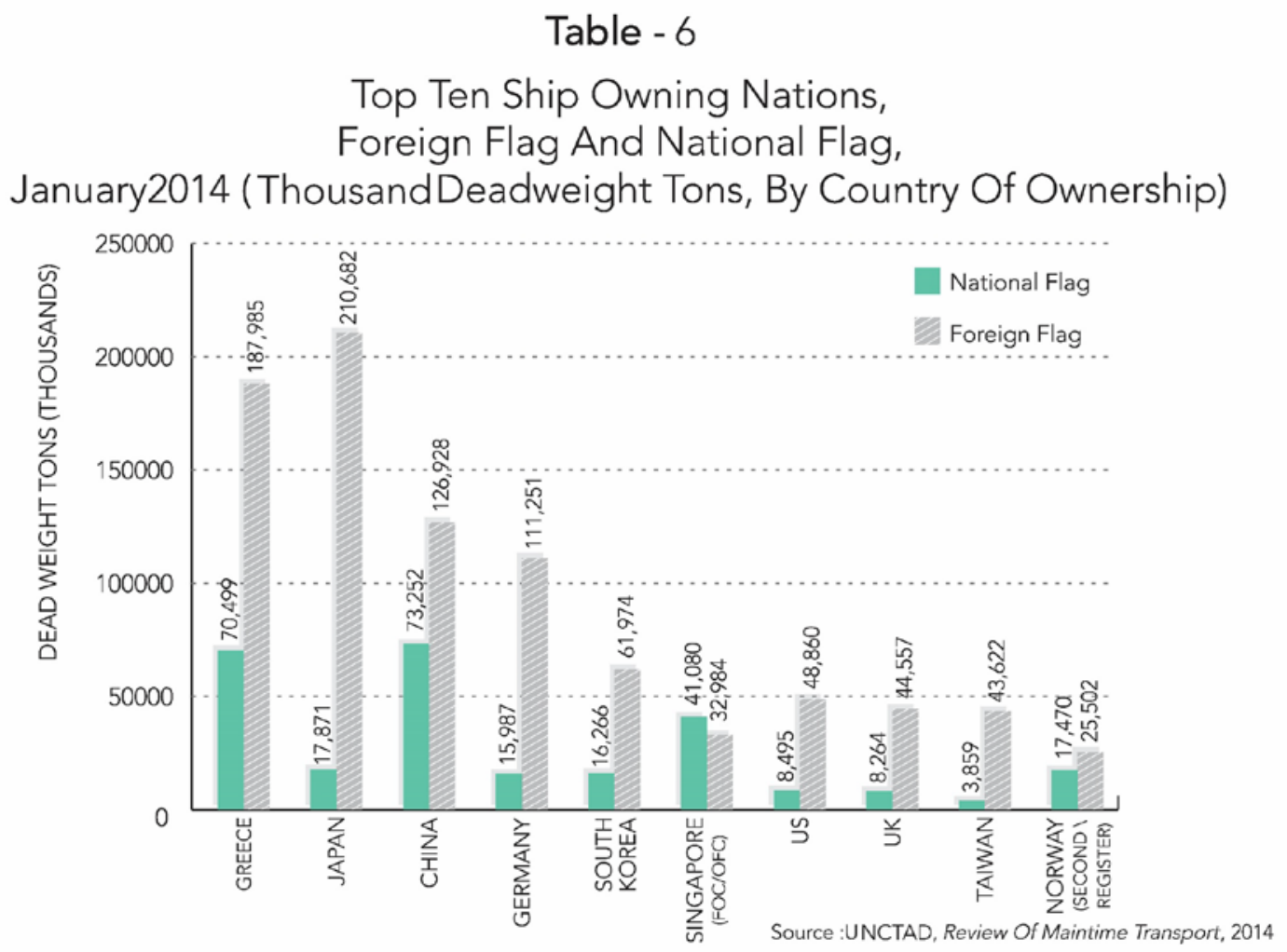

FOCs shift responsibility for environmental costs. Environmentalists have become the FOC institution's newest antagonists as effective nationalist opposition declines. The frequent murkiness of ship registration and ownership (produced primarily by FOCs) greatly weakens public and private efforts to limit shipping's environmental damage (Button 2005,48). This makes state intervention and legal regulation problematic and private bargaining between affected parties difficult. FOC vessels have a proclivity to illegal overfishing, oil spills, and other activities which despoil oceans and coasts.

Although unsuccessful in getting TNCs to abandon FOCs for the flags of metropolitan countries, environmentalists have encouraged FOC states to adopt conventions on pollution, safety and fishing as public relations exercises, which disguise the general lack of interest that shipowners and FOC governments have in these problems. Ratification of environmental conventions is different from the ratifying state moving effectively against vessels flying its flag, especially as few conventions and treaties contain provisions for any effective action against passive flag states (Carr and Scheiber 2004, Ferrell 2006). The ideology of a vessel as "a floating piece of the territory of the nation whose flag it flies” (Warner-Kramer 2004, 503) restricts actions by third parties. The FOC institution gives powerful incentives for open registries ${ }^{12}$ to flag as many vessels as they can and give their owners tax, secrecy, financial, labour cost, and anti-environmental advantages (OECD [Organisation for Economic Cooperation and Development] 2003, 2005).

Flags of convenience move toward a conceptualization of a global ocean, in the direction of a libertarian freedom of the seas as the standard ideology. This maritime globalism supersedes nationalism--which saw seas as extensions of individual nation-states or nationally based empires, e.g.,

12 "Flags of convenience” are more likely to be called “open registries” or “flags of necessity” by their supporters. 
the British or French Empires. It thwarts regionalism--which proposes that the seas are maritime arcs that are created by formal or informal regional political-economic systems or trading systems such as the European Union. It challenges basinism - which proposes that the seas are most meaningfully divided into a small number of bounded macro-areas, such as, the Atlantic, Pacific and Indian oceans. Instead FOCs push toward libertarian globalism--a single world ocean of global flows and processes, where the rules are increasingly defined by the expanding free markets across the world (Lewis 1999; Wigen 2011). Globalism does not just replace nationalism, regionalism and basinism; it changes their frame of reference.

Nationalism underpins the most persistent resistance to FOCs. FOC shipping has relentlessly triumphed over national maritime capital and labour-creating antagonism in the core states from the late 1940s, which disintegrated and passed to semi-peripheral and peripheral states in the 1960s and 1970s, before atrophying in the 1980s and 1990s. Nationalist projects sought to bring shipping under national bureaucratic or corporate control and ownership-using such means as cargo reservation, differential port charges and port capacity assignment (Frankel 1987, 32-6).

Rising independent Third World states brought tense and even furious confrontations at international forums with core states whose companies dominated FOC use. Developing world leaders contended that FOCs reinforced western-dominated unequal structures of the international division of labour, military power and commodity exchange. But the appeal of this maritime nationalism was vitiated by a global shipping depression in the 1970s, the Third World debt crisis and undercapitalization from the early 1980s, the disintegration of the semi-peripheral and peripheral countries of the Second World in the late 1980s and early 1990s, and the general moves toward global capitalism and deregulation. Leninist and developing world national elites were losing their nationalism and increasingly becoming part of the transnational capitalist class. The triumph of transnational corporations since the early 1970s weakened opposition to FOCs.

Contemporary business people in the Global South see FOCs as providing cheaper and more efficient shipping and higher profits than possible under their national flags, effectively reducing opposition to them-as when Mercator Lines, India's second largest private shipping company, registered Kamakshi Prem, a newly acquired \$168m oil tanker, in the Marshall Islands, the first major direct challenge to that country's nationalistic maritime and tax rules (Mint, Delhi, June 23, 2008). Furthermore, Asian governments which gain revenues from supplying labour to the increasing number of vessels flying FOCs were among the first to break ranks with other developing world countries. Low-wage Asians and eastern Europeans now constitute the majority in global crews (Lillie 2004). Developing world hopes for liner shipping under national flags faded as single national sources of products and point-to-point ocean transportation declined.

Sovereignty is fundamental to the flag of convenience institution, which has produced many of the deep structures of offshore financial centres. ${ }^{13}$ The doctrine of the sovereign equality of states and flag state control over vessels justifies the FOC system in international law. The general acceptance and conflicting interpretations of sovereignty among nationalists, unionists and environmentalists (plus their own incompatible objectives) weaken and fragment their anti-FOC campaigns. Transnational corporations (in alliance with lawyers and the American and British military) exploit loopholes in prevailing conceptions of sovereignty and have played vital roles in developing FOCs.

Lawyers are integral to FOC development. A wave of FOC lawyers has largely supplanted the old "gentleman" lawyer who registered ships under his national flag, using good manners, social connections, and reciprocal favours to gain state protection and subsidies. FOC lawyers were among the first "yuppies," creating new conventions regarding the transnational economy with the aim of eliminating the welfare state, at least in global maritime transportation.

The most successful FOC lawyers must have close ties with transnational maritime industries, which involve them in the margins of legal studies. Law practices defending corporations in tax, labour, occupational safety, and the environment have relatively low prestige among the traditional legal elite, more oriented (in the United States) to areas such as human rights and philanthropic charities--giving them greater legitimacy in terms of images of neutrality, gentility, and defending wider interests. FOC law requires new frameworks for contracts and new concepts to address new circumstances, in a sphere where many fundamental issues remain unresolved. FOC lawyers' dedication to changing rules to favour powerful transnational clients gives them power. They develop and take advantage of the latest trends in ship financing and respond to shipowners' specialised needs

\footnotetext{
${ }^{13}$ FOCs have been generally neglected in the academic literature on OFCs. Hampton (1996, 23; 1999, 417, 427) and Palan, Murphy and Chavagneux (2010, 23, 127), for example, mention FOCs as important OFC activities, but like many other accounts of OFCs devote very little attention to them.
} 
(in terms of their markets, liner or bulk operations, crew problems, union problems ${ }^{14}$, political problems, tax problems, or port state control problems).

Legal advice figures prominently in a successful open registry's organization-with amendments to FOC laws plus frequent supplementation of maritime regulations and adoption of international conventions. The fundamental principles of FOC shipping have been extraordinarily viable since Liberia and Panama FOCs emerged after World War II. These principles have been globalised by a continuous process of legal transplants (borrowings) between the growing number of major FOC registers around the world (see Table 1; for the Vanuatu case of legal transplants, van Fossen 2015). FOC lawyers are irreplaceable because highly legalistic conflicts arise-particularly between FOC laws and the complex and often contradictory laws of port states and the owners' and operators' states. Conflicts of extraterritoriality demand specialised legal knowledge and contribute to the development of FOC law itself. The ambiguities and complications of international maritime law and ownership of operational structures of FOC vessels mean that accidents involving them could become the substance of lawyers' dreams of eternal litigation. The market for legal services has expanded and globalised as institutions such as FOCs have removed economic activities from effective national state regulation, allowing lawyers to find loopholes, exceptions and opportunities in the conflicts within the old state system, so that their clients can increasingly choose their own laws from all that the world has to offer (see Carlisle 1981; Dezalay and Garth 2004; van Fossen 1992, 2012a).

Some FOC states have attempted to blunt criticism and gain international respectability through making alliances with prestigious global maritime organizations such as the International Maritime Organization (IMO), a UN agency which promotes rules but cannot enforce them. To some extent, this shifts concern from labour relations to technology and equipment.

By trying to create a club of high quality FOC registers adhering to collective standards, some open registers are trying to avert possible OECD initiatives against FOCs. The OECD emphasises that its general anti-OFC initiatives threaten FOCs, which the OECD presents as distorting global shipping taxation, lowering labour standards, facilitating money laundering, and disproportionately registering substandard vessels creating environmental (e.g., fishing piracy) and safety problems borne by the insurance industry and the wider community, not by owners or FOC states (OECD 2001, 2003, 2004, 2005). Apart from the OECD's specific attack on FOC shipping, its general campaign against tax havens is seen as an additional assault on flags of convenience (Fairplay, August 29, 2002).

\section{Transnational capitalist class and transnational capitalist state}

The dominant view in the Transnational State sees club formation in the maritime registry business as leading to a "race to the middle" (DeSombre 2006). The Transnational Capitalist Class and the Transnational Capitalist State are oriented toward stabilising the global system (unlike the increasingly uncompetitive national bourgeoisies and national states). The Transnational Capitalist Class and Transnational Capitalist State are not driven by national allegiances, but they are divided into three contending fractions-libertarians, structuralists, and regulationists. ${ }^{15}$ Each of the three principal fractions of the Transnational Capitalist Class and Transnational State outlined by Robinson and Harris (2000) corresponds to a distinctive policy toward flags of convenience.

Libertarians (e.g., at Washington-based foundations such as Cato, Heritage and the Center for Freedom and Prosperity) support flags of convenience and jurisdictional competition, which they see as vital in spurring efficiency, cost reduction ${ }^{16}$ and innovation. They view "open registries" as providing a virtuous alternative to unjust extortion by high-tax OECD governments, labour unions, and wellconnected crony shipowners. Libertarians present this alliance as supporting government subsidies and national monopolies to impose disadvantageous labour, regulation and taxation regimes on genuine shipping entrepreneurs and the general consuming public. Libertarians attack national flag shipping as inflaming nationalism and reducing the ability to respond to catastrophes through nationalist cargo reservation-hence constituting a threat to global peace and real national security (Linciome 2015; Mitchell 2004). The libertarian fraction favours a relatively decentralised world of sovereign nationstates, competing with one another fairly on the level playing field of free markets, each seeking new and improved ways of attracting capital and creating opportunities for free enterprise globalization.

\footnotetext{
${ }^{14}$ Union problems are most likely to come from the International Transport Workers Federation, which for decades attempted to stop the transition to FOCs. Today it principally tries to improve wages and working conditions for crews aboard flag of convenience vessels.

${ }^{15}$ The terms "structuralist” and "regulationist" are from Robinson and Harris (2000, 42) and Harris (2013, 743). I use the term "libertarian" rather than their phrase "free market conservative" for the sake of clarity (e.g., some conservative organizations such as the Roman Catholic Church may be critical of free markets).

16 "The cost of sea transport fell by $80 \%$ between 1970 and 2000 . . . The transfer of ownership to Flags of Convenience is arguably the most important contributor to cost reduction” (Mitchell 2004, 8).
} 
This faction was temporarily weakened by 11 September 2001 terrorist attacks and the 2008 Global Financial Crisis, but the lingering global recession has strengthened the libertarian hard core and its commitment to flags of convenience, which have become even more prominent over the last decade.

Structuralists (e.g., International Maritime Organization of the United Nations, the private ship classification societies) divide "good" from "bad" FOC registries. Structuralists seek to impose minimum structural standards on registries generally. They see FOC registries' policies extending beyond these registries' borders and think that they must be assessed in terms of their effects on other countries. Structuralists suggest that some "bad" FOC jurisdictions are under-resourced, informationdeprived, and politically constrained in dealing with clients whose activities threaten other countries. They insist that all FOC registries must enact laws and create institutional structures to meet minimum standards, so that they are able to play their valuable role in the global economy through "structural isomorphism” (Meyer 2010). Structural policies are supported by most governments, many TNCs and many large global financial institutions in the Global North, especially since the standards can be easily met (at least rhetorically) by the several of the largest FOC registries such as Liberia and the Marshall Islands, with little effect on the profits arising from FOC use.

Key transnational institutions such as the IMO, which is funded principally and increasingly by FOC states, see established FOC registries as raising standards--joining an emerging club of higher quality open registries. According to this view, new entrants into the FOC business compete by offering low standards, but are brought into line by their desire to go up-market. In any case, the FOC system, in cooperation with the IMO, is seen as correcting its problems over time, providing a peaceful global environment for the growth of shipping in a post-colonial world.

Regulationists (e.g., the central bureaucracies of the OECD and European Union) favour severely curtailing or even eliminating FOCs, which they see as acting against the global public interest. Regulationists view FOCs as serving only the interests of the least productive and most parasitic capitalists. They favour greater cooperation across national borders to produce a more equitable and coordinated global maritime system, which will sideline national sovereign equality by requiring generalised high standards. Regulationists are most closely aligned with factions of transnational industrial capital which cooperate with social democratic states and organised labour in corporatist arrangements.

An increasing number of traditional maritime countries in the OECD have opened second registers or quasi-FOCs (beginning with Norway in 1987). Initially considered the greatest threat to FOCs, they are now effectively way-stations between traditional flags to FOCs. Proclaimed as combining some of FOC tax and manning advantages with the safety standards and legitimacy of a genuine link between flag and vessel, they have been pressured to resemble FOCs-some even risk being classified as FOCs. Second registers' stronger link than between a pure FOC vessel and its country of registration is a structural problem for investors. Shipping and taxation policy becomes a matter of domestic political concern and debate-increasing shipowners' frustration, pushing them to FOCs. A potential European Community flag would probably eliminate second registers but fail to compete with FOCs (Coghlin 1990). Second registers are reactive, not proactive, and create no significant threat to FOCs under current circumstances. FOCs have demonstrated their comparative advantages over second registers or quasi-FOCs promoted by countries such as Norway.

The most that can be said of the regulationists' anti-FOC campaign is that it has provided a few respites in a long-term decline of national shipping. It has partially succeeded in somewhat limiting environmental damage. It has helped a bit to raise seafarers' wages and working conditions aboard FOC vessels (making limited progress in establishing a global minimum wage at very low levels). It has taken some preventative action against employers or home governments confiscating back-pay, although its effectiveness in keeping these seamen off "black lists" at home in labour supplying countries such as the Philippines is debatable. It has not succeeded in stemming the long-term growth of FOC shipping and spreading FOC-like conditions on national flag vessels (Fairplay, August 2, 2007).

In summary, different types of transnational capital support the three different policies toward FOCs. Libertarians strongly support FOCs as representing a pure form of unregulated beneficial capitalism. Libertarians believe in utopian, efficient, self-correcting free markets. Structuralists (who, in the case of FOCs, are quasi-libertarians) contend that FOCs should be accepted if they adhere to the broad minimum standards, set by emerging transnational political institutions (particularly the International Maritime Organization of the United Nations) to ensure stability in global ocean transportation. Regulationists are strong critics of FOCs, which they see as defeating wider social (e.g., labourite, environmental) interests.

FOCs are virtual libertarian spaces, providing the Transnational Capitalist Class with the greatest powers of action. They increasingly define the terms that bind together the productive units of global 
capitalism--and push the system toward laissez-faire. Flags of convenience represent a libertarian victory that has been unfolding over the past five decades. FOCs are libertarian in-

- $\quad$ reducing costly environmental, health, safety and financial regulations

- $\quad$ minimising taxes, wages, subsidies, and effective fair employment laws

- weakening licensing (safety and operational classifications of ships and certification of mariner competence)

These libertarian moves have (so far) mostly failed or had limited success on land, but they have largely prevailed at sea. FOCs and other successful libertarian advances (e.g., floating currencies) respond to crises or near-crises, that the existing system (e.g., national flag shipping, Bretton Woods fixed currency exchange rates) failed to resolve. Applying Meltzer's (2004) model explaining libertarian victories and connecting it to the history of flags of convenience (Carlisle 1981; van Fossen 1992, 2012a), we can see that libertarian victories such as the growing use of FOCs have a greater chance of success if-

- $\quad$ they are already known (FOCs existed on a very minor scale for centuries and on a small but ever more noticeable scale for decades before the late 1960s)

- $\quad$ their supporters have already formulated extensive answers to critics (including slogans such as "flags of necessity" to justify FOCs)

- the political elite has enough familiarity with the libertarian alternative to believe that it can work (the US State and Defense Departments and the CIA initially assisted oil company lawyers in developing the Liberian FOC)

- libertarians can bypass lawyers who typically propose more laws and regulations to resolve the crisis (a coterie of globally oriented "yuppie” entrepreneurial lawyers developed FOCs and displaced old national flag "gentleman" lawyers)

- they can draw on support of the general public (which has been convinced, to the extent that there is any general opinion, that FOCs and transportation deregulation benefit consumers)

- $\quad$ antagonistic social movements (e.g., organised labour, environmental, nationalist) can be neutralised

Yet the libertarian "solutions” represented by flags of convenience aggravate the problems of severe cycles in shipping. Ships are highly speculative assets, with volatile revenue flows and asset values and low average profit levels. While conventional neo-classical and libertarian economics contends that investors are rational and so would predict low investment in shipping, the industry has in fact suffered from too much investment. Overinvestment and over-ordering of ships and then "profit squeezes" are perennial problems in shipping. Overcapacity and depression were particularly acute from 1973 to 1988 — with the 1982-87 depression having been the most extreme since 1775-only to be followed by the even more severe depression from 2008 to present. There was a boom from 1988 to 1997 and the boom from 2003 to 2008 was the most dramatic in 264 years (Stopford 2009).

Poorly conceived investment in shipping during booms has been disastrous for the original investors. Yet it has provided enormous profits (even fortunes) for experienced, well-informed, canny and manipulative shipowners who buy during shipping depressions and sell during booms. In this way, shipping is very similar to gambling, with one investor's gain often being another investor's loss. As such, shipping's reality provides a significant challenge for the unreal, formal, rationalist neo-classical economics that is at the heart of neo-liberalism and libertarianism. Shipping dramatises many of the points made by Shiller (2015) and Akerlof and Shiller (2015) about the extreme imperfections and unreliability of "free" markets in the real world-and their tendencies toward "irrational exuberance" and crisis.

The Global Financial Crisis (GFC) of 2008 was followed by significant growth in the tonnage under FOCs (see table 4). ${ }^{17}$ After the GFC shipping entered into a crisis of stagnating global trade, low freight rates and structural overcapacity from which it has not recovered. The response has been austerity - to cut wages and costs by flagging out even more vessels to FOCs and building larger ships (Handelsblatt Global Edition, June24, 2015). What is rational for the individual capitalists is frequently self-destructive for capital generally. Collective rationality in this post-GFC world would bring a reduction in shipping capacity. Instead, the biggest shipowners, locked into the prisoner's dilemma, do the opposite. The biggest shipping lines, particularly in the container trade, are ordering larger ships to take advantage of economies of scale and reduced unit costs-even though this will drive shipping

\footnotetext{
${ }^{17}$ This was true of all major sectors. Between 2005 and 2010, for example, the percentage of gross tons under FOCs went from $69.0 \%$ to $71.3 \%$ of crude oil tankers, from $77.1 \%$ to $77.6 \%$ of offshore (mostly oil and gas) structures, from $72.8 \%$ to $75.9 \%$ of dry bulk ships, and from $59.1 \%$ to $68.3 \%$ of container ships (Lloyd's Shipping Register, World Fleet Statistics, 2005-2011).
} 
rates even lower. The largest companies believe the depressed rates will force their weaker competitors to surrender-through forced mergers or bankruptcy (Financial Times, September 9, 2015).

Although this seems to be ruthless free market competition, there are severe contradictions in this process. Shipyards building these massive new ships and the vast new infrastructures that are necessary to handle them are being subsidised by public money. While ship owners increasingly use FOCs and avoid taxation, they demand that taxpayers provide enormous amounts for new and deeper ports, harbour dredging and hinterland infrastructure necessary for their FOC operations—or lose competitive advantage. FOC ships grow larger and make more demands on public infrastructure, at the very time that the general economy is stagnating. The OECD's anti-FOC campaign is coordinated with its resistance to the enormous infrastructure costs that are being imposed on governments by the current deregulated, untaxed FOC shipping system (OECD 2015a). Furthermore, the OECD has recently warned of a further, more radical contradiction. The FOC system and associated tax haven structures are crucial parts of the destructive forces that act to depress investment in high-wage, high-tax, and high-consumption zones of the world economy (despite almost zero interest rates since the GFC). Instead, enormous investment is outsourced to low-tax, low-wage zones that repress labour and consequently do not produce real middle-class consumer groups or enough new demand to prevent the global economy from sinking into a further crisis (OECD 2015b). FOC shipping is crucial in connecting these zones of the world economy and accelerating these contradictory processes.

\section{Conclusion}

Capitalism entered a crisis in the late 1960s, for which globalisation was the answer. The national flag cargo shipping system was seen as too expensive and restrictive to allow global capitalism to emerge.

A new libertarian transoceanic system based on flags of convenience developed to solve these crucial problems for capitalism. FOCs dramatically lower costs of global transportation. They weaken maritime nationalism and organised labour. They encourage the intermodalism that deregulates sea, land and air transportation around the world. They help to generate the global division of production that supplants national capitalism.

The globalised flag of convenience system is beset by internal contradictions-most crucially, the general problems of overcapacity, low profitability, and acute cycles of booms and bust. The "solutions" to these internal contradictions have been to be more competitive by reducing costs (and almost suicidal rate cutting). This is accomplished through taking advantage of economies of scale. This further concentrates the shipping industry in the largest firms through alliances, mergers and acquisitions. It leads to building even bigger ships. Shipping relies even more on flags of convenience to reduce taxes, labour and regulatory costs.

Yet these "solutions" have only made the contradictions of the flag of convenience global shipping system more acute. This seemingly libertarian system actually relies on large taxpayer-funded subsidies for building new ships, ports and other infrastructure. Whatever the contradictions, the end result has been that capitalism globalizes further and flag of convenience shipping grows even larger. The most crucial questions for the future are whether these contradictions will result in a profound crisis for the global economy and how this crisis will be resolved.

\section{Notes on contributor}

Anthony van Fossen is adjunct research fellow in the social sciences at Griffith University in Brisbane, Australia. He has written extensively on tax havens, global capitalism, and politics, economy, and society in the Pacific Islands. His latest book is Tax Havens and Sovereignty in the Pacific Islands.

\section{References}

Akerlof, G. A., and Robert J. Shiller. 2015. Phishing for Phools: the Economics of Manipulation and Deception. Princeton: Princeton University Press.

Bonacich, E., and J. B. Wilson. 2008. Getting the Goods: Ports, Labor and the Logistics Revolution. Ithaca: Cornell University Press.

Broeze, F. 2002. Globalisation of the Oceans. St. John's, Newfoundland: International Maritime Economic History Association.

Button, K. 2005. “Shipping Economics.” Maritime Policy and Management 32 (1): 39-53.

Carlisle, R. 1981. Sovereignty for Sale. Annapolis: Naval Institute Press.

Carr, C. J., and H. N. Scheiber. 2004. “Dealing with a Resource Crisis.” In Dynamics of Regulatory Change, edited by D. Vogel and R. Kagan, 118-55. Berkeley: University of California Press.

Coghlin, J. 1990. "Common Maritime Transport Policy for the EEC.” Boston College International and Comparative Law Review 13 (2): 447-63,

Cudahy, B. J. 2006. Box Boats: How Container Ships Changed the World. New York: Fordham University Press. DeSombre, E. 2006. Flagging Standards. Cambridge, Massachusetts: MIT Press. 
Dezelay, Y., and B. Garth. 2004. “Confrontation between the Big Five and Big Law.” Law and Social Inquiry 29 (3): 615-38.

Dicken, P. 2015. Global Shift. 7th ed. New York: Guilford Press.

Ferrell, J. 2005. “Controlling Flags of Convenience.” Environmental Law 35 (2): 323-390.

Frank, R. H., and B. S. Bernanke. 2013. Principles of Economics. 5th ed. New York: McGraw-Hill Irwin.

Frankel, E. 1987. World Shipping Industry. London: Croom Helm.

Goulielmos, A., and M. Psifia. 2006. “Shipping Finance.” Maritime Policy and Management 33 (3): 301-320.

Harlaftis, G. 1996. A History of Greek-Owned Shipping. London: Routledge.

Hampton, M. 1996. Offshore Interface. London: Macmillan.

Hampton, M. 1999. “Exploring the Offshore Interface.” edited by M.K. Lewis Globalization of Financial Services, 415-39. Cheltenham: Edward Elgar.

Harris, J. 2005. “To Be or Not to Be: The Nation-Centric World Order Under Globalization.” Science and Society 69 (3): 329-40.

Harris, J. 2013. “Transnational Politics, Class Conflict, and the State.” Globalizations 10 (5): 731-46.

Harris, J. 2014. “Transnational Capitalism and Class Formation.” Science and Society 78 (3): 312-33.

Heidbrink, I. 2011. "The Business of Shipping: an Historical Perspective.” In Blackwell Companion to Maritime Economics, edited by W. K. Talley, 34-51. Malden, Massachusetts: Wiley-Blackwell.

Hein, M. 2015. "Globalizing the Nation-State: The Shipping Container and American Infrastructure.” Mobilities 10 (3): 345-62.

Keaveny, C., and S. Murray. 2013. “Aviation Finance and Leasing.” Offshore Investment 239 12-14.

Kennedy, D. 1997. A Critique of Adjudication (fin de siècle). Cambridge, Massachusetts: Harvard University Press.

Krugman, P., R. Wells, and K. Graddy. 2008. Economics. New York: Worth.

Lane, T. 2007. “Shipping Revolution.” In Oxford Encyclopedia of Maritime History, vol. 3, edited by J. B. Hattendorf, 677-85. Oxford: Oxford University Press.

Levinson, M. 2006. The Box: How the Shipping Container Made the World Smaller and the World Economy Bigger. Princeton: Princeton University Press.

Lewis, M. W. 1999. “Dividing the Ocean Sea.” Geographical Review 89 (2): 188-214.

Lillie, N. 2004. "Global Collective Bargaining on Flag of Convenience Shipping.” British Journal of Industrial Relations 42 (1): 47-67.

Linciome, S. 2015. "If You Like Higher Prices, Enriched Cronies, and Weak National Security, Then You'll Love the Jones Act.” Federalist, January 22.

Lloyd’s Register of Shipping. 1955-2011. World Fleet Statistics. London: Lloyd’s Register.

Meyer, J. 2010. World Society. Oxford: Oxford University Press.

Meltzer, A. H. 2004. “Choosing Freely: The Friedmans' Influence on Economic and Social Policy.” In The Legacy of Milton and Rose Friedman's Free to Choose: Economic Liberalism at the Turn of the $21^{\text {st }}$ Century, edited by M. A. Wynne, H. Rosenbaum, and R. L. Formaini, 191-205. Dallas: Federal Reserve Bank of Dallas.

Michie, J., ed. 2011. Handbook of Globalisation. 2nd ed. Cheltenham: Edward Elgar.

Miller, M. B. 2012. Europe and the Maritime World: a Twentieth-Century History. Cambridge: Cambridge University Press.

Mitchell, D. J. 2004. “The Threat to Global Shipping from Unions and High-Tax Politicians: Restrictions on Open Registries Would Increase Consumer Prices and Boost Cost of Government.” Propseritas (Center for Freedom and Prosperity Foundation) 4 (2): 1-26.

Morris, R., and T. Kilkauer. 2001. "Crews of Convenience from the Southwest Pacific.” New Zealand Journal of Industrial Relations 26 (2): 185-98.

OECD (Organisation for Economic Co-operation and Development). 2001. Cost to Users of Substandard Shipping. Paris: OECD.

OECD (Organisation for Economic Co-operation and Development). 2003. Cost Savings Stemming from NonCompliance with International Environmental Regulations in the Maritime Sector. Paris: OECD.

OECD (Organisation for Economic Co-operation and Development). 2004. Removal of Insurance from Substandard Shipping. Paris: OECD.

OECD (Organisation for Economic Co-operation and Development). 2005. Why Fish Piracy Persists. Paris: OECD.

OECD (Organisation for Economic Co-operation and Development). 2015a. Megaships: Trends and Rationale. Paris: OECD.

OECD (Organisation for Economic Co-operation and Development). 2015b. OECD Business and Financial Outlook. Paris: OECD.

Palan, R., R. Murphy, and C. Chavagneux. 2010. Tax Havens: The Real Meaning of Globalization. Ithaca: Cornell University Press.

Pettman, R., ed. 2012. Handbook of International Political Economy. Singapore: World Scientific Publishing.

Ritzer, G., ed. 2012. The Wiley-Blackwell Encyclopedia of Globalization. 5 vol. Oxford: Wiley-Blackwell.

Robinson, W. I. 2004. A Theory of Global Capitalism. Baltimore: Johns Hopkins University Press.

Robinson, W. I. 2014 Global Capitalism and the Crisis of Humanity. Cambridge: Cambridge University Press.

Robinson, W. I., and J. Harris. 2000. "Towards a Global Ruling Class?: Globalization and the Transnational Capitalist Class.” Science and Society 64 (1): 11-54.

Samuelson, P. A., and W. D. Nordhaus. 2010. Economics. 19th ed. New York: McGraw-Hill Irwin.

Shiller, R. J. 2015. Irrational Exuberance. 3th ed. Princeton: Princeton University Press. 
Stopford, M. 2009. Maritime Economics. London: Routledge.

UK Department of Transport. 2015. World Fleet Statistics. London: UK Department of Transport.

UNCTAD (United Nations Conference on Trade and Development). 2014. Review of Maritime Transport. New

York: United Nations.

van Fossen, A. 1992. The International Political Economy of Pacific Islands Flags of Convenience. Nathan, Brisbane: Griffith University Centre for the Study of Australia-Asia Relations.

van Fossen, A. 1999. "Globalization, Stateless Capitalism and the International Political Economy of Tonga's Satellite Venture.” Pacific Studies 22 (2): 1-26.

van Fossen, A. 2012a. Tax Havens and Sovereignty in the Pacific Islands. St. Lucia, Brisbane: University of Queensland Press.

van Fossen, A. 2012b. "The Transnational Capitalist Class and Tax Havens.” In Financial Elites and Business: Who Rules the World?, edited by Georgina Murray and John Scott, 76-99. Cheltenham: Edward Elgar.

van Fossen, A. 2015. "Law and Political Economy in Vanuatu's Tax Haven." Comparative Law Journal of the Pacific (Special Issue 18: Tax Issues in the South Pacific, edited by Xavier Cabannes): 157-178.

van Fossen, A. 2016. “Offshore Tax Havens: the Borderlands of Global Capitalism.” In Globalization and Transnational Capitalism in Asia and Oceania, edited by J. Sprague, 145-162. London: Routledge.

Warner-Kramer, D. 2004. "Control Begins at Home.” Golden Gate University Law Review 34 (3): 497-529.

Wigen, K. 2011. "Cartography of Connection: Ocean Maps as Metaphors for Inter-Area History.” In Immanuel Wallerstein and the Problem of the World: System, Scale, Culture, edited by D. Palumbo-Liu, B. Robbins, and N. Tanoukhi, 138-154. Durham, North Carolina: Duke University Press. 